\title{
Plummer-Vinson Syndrome and Esophageal Cancer in an Endoscopy Center of Dakar
}

\author{
Marie Louise Bassene1, Salamata Diallo1, Mame Aïssé Thioubou1, Mamadou Ngoné Gueye1, \\ Marième Polèle Fall'1, Daouda Dia ${ }^{2}$, Mouhamadou Mbengue ${ }^{2}$, Mamadou Lamine Diouf ${ }^{1}$ \\ ${ }^{1}$ The Department of Hepato-Gastroenterology, Aristide le Dantec Hospital, Dakar, Senegal \\ ${ }^{2}$ The Department of Hepato-Gastroenterology, General Hospital of Grand Yoff, Dakar, Senegal \\ Email: marielouisebassen@yahoo.fr
}

How to cite this paper: Bassene, M.L., Diallo, S., Thioubou, M.A., Gueye, M.N., Fall, M.P., Dia, D., Mbengue, M. and Diouf, M.L. (2017) Plummer-Vinson Syndrome and Esophageal Cancer in an Endoscopy Center of Dakar. Open Journal of Gastroenterology, 7, 217-222.

https://doi.org/10.4236/ojgas.2017.78023

Received: June 30, 2017

Accepted: August 13, 2017

Published: August 16, 2017

Copyright $\odot 2017$ by authors and Scientific Research Publishing Inc. This work is licensed under the Creative Commons Attribution International License (CC BY 4.0).

http://creativecommons.org/licenses/by/4.0/

\begin{abstract}
Introduction: Plummer Vinson Syndrome (PVS) is a rare pathology combining dysphagia, an iron deficiency anemia and a cervical esophageal web. It is one of the risk factors of the esophageal cancer. Objectives: To report the epidemiological, clinical, paraclinical and histological characteristics of patients with Plummer-Vinson syndrome associated with esophageal cancer. Patients and Methods: This was a retrospective study carried out at the digestive endoscopy center of Aristide le Dantec hospital in Dakar from January 2008 to December 2015. We included all patients with Plummer-Vinson syndrome associated with esophageal cancer. Results: We included 7 patients. The mean age was 36 years ( $24-65$ years). There were 5 women and 2 men. The mean diagnostic period was 9 months (6 months - 15 years). The main clinical manifestations were dysphagia (100\%), weight loss (100\%) and clinical anemia (71.4\%). The biology showed a mean hemoglobin level of $8.8 \mathrm{~g} / \mathrm{dl}(6-11 \mathrm{~g} / \mathrm{dl})$, serum iron at $30.8 \mu \mathrm{g} / \mathrm{dl}(11-52 \mu \mathrm{g} / \mathrm{dl})$ and ferritinemia at $6.2 \mathrm{ng} / \mathrm{dl}(1.5-25$ $\mathrm{ng} / \mathrm{dl})$. The upper digestive endoscopy revealed a stenosis web of the cervical esophagus in all patients. An endoscopic dilatation was performed in all cases. After dilation, the endoscopy showed a tumor of the middle third of the esophagus in 4 cases and of the lower third in 3 cases. It was about of a squamous cell carcinoma in the tumors of middle third and of an adenocarcinoma in those of the lower third. Conclusion: At Aristide le Dantec hospital of Dakar, PVS is sometimes associated with an epidermoid carcinoma or an adenocarcinoma of the esophagus. The improvement of the prognosis depends on the early realization of an upper gastrointestinal endoscopy (UGI) in case of any dysphagia and the monitoring of the patients.
\end{abstract}

\section{Keywords}

Plummer-Vinson Syndrome, Esophageal Cancer, Dysphagia, Senegal 


\section{Introduction}

Plummer-Vinson syndrome (PVS), also known as Paterson-Kelly syndrome or sideropenic dysphagia, is a rare pathology combining dysphagia, iron deficiency anemia and cervical esophageal web. Being common in northern countries in the early twentieth century, it has become very rare nowadays.

Declining prevalence is linked to the improvement of the nutritional status of the population. In Africa and Asia, cases of PVS are reported in some regions due to poor sociodemographic conditions [1]-[7].

PVS is one of the risk factors of cervical esophageal, hypopharynx and tongue cancer [8] [9] [10] [11]. Its association with middle esophagus or distal esophagus cancer is exceptional [7] [12] [13]. Malignant degeneration occurs in 3\% to $15 \%$ of cases [9] [10].

We report the epidemiological, clinical, paraclinical and histological characteristics of patients with Plummer-Vinson syndrome associated with esophageal cancer at the endoscopy center of Aristide le Dantec Hospital.

\section{Patients and Methods}

This is a retrospective study carried out in the digestive endoscopy center of Aristide le Dantec hospital in Dakar during the period from January 2008 to December 2015.

The subjects studied were all the patients who went to the center for UGI endoscopy.

We included all the patients with PVS associated with esophageal cancer. We excluded the patients whose histological record was not available.

In the medical records of the patients, we collected and analyzed the epidemiological, clinical, paraclinical and histological data.

\section{Results}

There was PVS associated with a macroscopic appearance suggestive of esophageal cancer in 9 patients.

We excluded from the study 2 patients whose histological review was not available. Thus, we studied 7 patients. The average age was 36 years ( $24-65$ years). There were 5 women and 2 men.

The average diagnostic period was 9 months (6 months - 15 years).

The main clinical manifestations were dysphagia (100\%), weight loss (100\%), clinical anemia (71.4\% of cases) and angular cheilitis (57.1\%). There was no history of smoking, drinking alcohol or drinking very hot drinks.

Biological tests showed an iron deficiency in all patients. The mean hemoglobin level was $8.8 \mathrm{~g} / \mathrm{dl}(6-11 \mathrm{~g} / \mathrm{dl})$, mean corpuscular volume (MCV) at $72 \mathrm{fl}(71$ - $88 \mathrm{fl})$, mean serum iron level at $30.8 \mu \mathrm{g} / \mathrm{dl}(11-52 \mu \mathrm{g} / \mathrm{dl})$ and the mean ferritin level at $6.2 \mathrm{ng} / \mathrm{dl}(1.5-25 \mathrm{ng} / \mathrm{dl})$.

The UGI endoscopy demonstrated an impenetrable stenosis web of the cervical esophagus in all patients. 
An endoscopic dilation with Savary-Gilliard bougies was performed in all cases. After dilatation, an endoscopy check revealed a localized tumor in the middle third in 4 cases and the lower third in 3 cases.

The tumor was ulcerous-budding in 57.1\% of cases and haemorrhagic in $71.4 \%$ (see Table 1). The histology of the lesions was in favor of squamous cell carcino$\mathrm{ma}$ in all cases of middle esophageal tumor and adenocarcinoma in those of the lower third (see Table 2).

\section{Discussion}

In northern countries, the PVS incidence rate has fallen thanks to the improvement of the food quality in parallel with, the improvement of the system and, better management of the pregnant women [9]. In southern countries where economic resources are limited, cases of PVS are still described [1]-[7].

PVS is recognized as a risk factor for cancer of the upper digestive tract mainly the esophagus. A previous study on PVS conducted in the department found a prevalence of $1.03 \%$ [1].

In our study, we report cases of association of the PVS with esophageal cancer in 7 cases. This association is known and was reported in the form of clinical cases in the literature. The rarity of PVS explains the reduced size of the described series. The average age of patients was 36 years and the sex ratio 0.4 according to the literature in which malignant degeneration occurs most frequently in 15 to 50 years old female in 3 to $15 \%$ of cases [14] [15].

Dysphagia is the main symptom in this pathology. It was present in all our patients. It generally progressed over several years, it is intermittent and painless, progressively worsened, often neglected. This clinical latency partly explains the

Table 1. Macroscopic aspect of the esophageal cancer.

\begin{tabular}{ccc}
\hline Macroscopic aspect & Number & $\%$ \\
\hline Ulcero-budding & 4 & 57.1 \\
Budding & 2 & 28.6 \\
Ulcerated & 1 & 14.3 \\
Hemorrhagic & 5 & 71.4
\end{tabular}

Table 2. Epidemiology of patients and tumor characteristics.

\begin{tabular}{ccccc}
\hline Patients & Age & Gender & Site of esophageal tumor & Histology of tumor \\
\hline 1 & 24 & M & Middle & Squamous cell carcinoma \\
2 & 29 & F & Middle & Squamous cell carcinoma \\
3 & 30 & F & Distal & Adenocarcinoma \\
4 & 30 & F & Middle & Squamous cell carcinoma \\
5 & 30 & F & Middle & Squamous cell carcinoma \\
6 & 44 & M & Distal & Adenocarcinoma \\
7 & 65 & F & Distal & Adenocarcinoma \\
\hline
\end{tabular}


long diagnostic period observed in patients. A malignant degeneration is suspected in recent aggravation of dysphagia with weight loss.

The detection of PVS was coincident with that of esophageal cancer. Other authors have also reported this association at the time of the initial diagnosis of PVS [3] [7] [9] [11] [12].

The pathogenesis of PVS remains poorly understood. It would be multifactorial, involving interlinked etiological factors such as iron deficiency, malnutrition, genetics and autoimmunity.

The iron deficiency appears to be a predominant etiologic factor. Indeed, cases of regression of the esophageal web and dysphagia after correction of deficiency anemia have been reported [4] [16] [17] [18] [19].

In a study conducted in 19 patients with PVS in the same endoscopic center, iron supplementation was associated with the esophageal dilation in all patients [1] as indicated in the literature [4] [5] [7] [10] [20] [21].

In our study, the endoscopic dilatation of the esophageal web allowed the detection of malignant neoformation in the esophagus and the performance of biopsies.

The histology was in favor of a squamous cell carcinoma of the middle esophagus in four patients and an adenocarcinoma of the lower esophagus in three patients. The mechanisms of carcinogenesis are poorly understood. They would pass through the atrophy of the digestive tract mucosa induced by iron deficiency [9].

It is usually a squamous cell carcinoma that can lie on the tongue, the hypopharynx or the esophagus [8] [9]. Three patients had esophageal adenocarcinoma. The association of a PVS with an esophageal adenocarcinoma has not been reported in the literature.

Cases of association of the PVS with gastric adenocarcinoma have been described [8] [22].

The PVS is therefore a preneoplastic field. An endoscopic surveillance is recommended. However its methods are not consensual [9]. The place of the otorhinolaryngology examination in this surveillance is not codified.

PVS is a rare disease whose evolution is usually favorable under treatment. However, it can be clouded by the occurrence of a malignant degeneration that can be life-threatening.

\section{Conclusions}

Esophageal cancer following a PVS is a serious evolving modality which precipitates the natural history of the latter.

At the endoscopy center of Aristide le Dantec hospital in Dakar, the association of PVS with esophageal cancer is most often found in a young woman. It is a squamous cell carcinoma of the middle esophagus or an adenocarcinoma of the lower esophagus.

Endoscopic and otorhinolaryngological surveillance of PVS should be better 
clarified.

\section{References}

[1] Dia, D., Diouf, M.L., Diouf, G., Mbengue, M., Bassène, M.L., Fall, S., et al. (2010) Le syndrome de Plummer-Vinson: Aspects cliniques, paracliniques et thérapeutiques. A propos de 19 cas à Dakar. Medecine d Afrique Noire, 5704, 189-192.

[2] Berthé, A., Diop, M.M., Toure, P.S., Tall, C.T., Faye, A.F., Diop, B.M. and Ka, M.M. (2014) Unusual Presentations of Plummer-Vinson Syndrome in Black African: Report of Two Cases. The Pan African Medical Journal, 19, 145.

[3] Vikas, S., Bela, P., Ajay, G. and Devang, G. (2006) A Case Study of Plummer-Vinson Syndrome. Indian Journal of Otolaryngology and Head and Neck Surgery, 58, 391-392. https://doi.org/10.1007/BF03049607

[4] Ben Dhaou, B., Ketari, S., Derbali, F., Saidane, L., Boussema, F. and Kochbati, S. (2009) Le syndrome de Plummer Vinson: A propos de 3 observations et revue de la littérature.

[5] Belfaquir, L., Krimissa, K., Oubahmane, T., Abada, R., Rouadi, S. and Janah, A. (2013) Syndrome de Plummer-Vinson: A propos de quatre cas et revue de la littérature.

[6] Iftekhar Rasool, S.M., Rezwana Begum, M., Ravichandra, K. and Prasanth, P.S. (2014) Revisiting Plummer Vinson Syndrome-A Report of Three Cases and Review. Malta Medical Journal, 26, 37-41.

[7] Badawy, S.B., Mohamed, A.K.A., Ramadan, H.S. and Tito, N.H. (2010) Role of Microsatellites Instability in Carcinogenesis of Postcricoid Carcinoma on Top of Plummer-Vinson Syndrome. Indian Journal of Otolaryngology and Head \& Neck Surgery, 62, 417-420. https://doi.org/10.1007/s12070-010-0111-8

[8] Kim, K.H., Kim, M.C. and Jury, G.J. (2005) Gastric Cancer Occurring in a Patient with Plummer-Vinson Syndrome: A Case Report. World Journal of Gastroenterology, 11, 7048-7050. https://doi.org/10.3748/wjg.v11.i44.7048

[9] Gandhi, L., Pramoda, K. and Manoop, S.B. (2016) Plummer-Vinson Syndrome Presenting as Squamous Cell Carcinoma of Esophagus. Journal of Digestive Endoscopy, 7, 71-73. https://doi.org/10.4103/0976-5042.189156

[10] Shamimul, H., Nabeel, I.K. and Ayesha, S. (2013) Plummer-Vinson Syndrome-A Premalignant Condition-An Overview of Literature. UJMDS, 1, 28-30.

[11] Boudabous, M., Yaich, K., Mnif, L., Chtourou, L., Amouri, A. and Tahri, N. (2012) Syndrome de Plummer Vinson et cancer du moyen oesophage: Une association pathogénique à propos d'un cas.

[12] Nasa, M., Patil, G., Sharma, Z. and Puri, R. (2017) Plummer-Vinson Syndrome with Simultaneous Mid-Esophageal Growth. Journal of the Association of Physicians of India, 65, 96-97.

[13] Novacek, G. (2006) Plummer-Vinson Syndrome. Orphanet Journal of Rare Diseases, 1, 36. http://www.OJRD.com/content/1/1/36 https://doi.org/10.1186/1750-1172-1-36

[14] Messmann, H. (2001) Squamous Cell Cancer of the Oesophagus. Best Practice \& Research: Clinical Gastroenterology, 15, 249-265. https://doi.org/10.1053/bega.2000.0172

[15] Hugo, E.A. (1936) Simple Achlorhydric Anaemia, Plummer-Vinson Syndrome and Carcinoma of the Mouth, Pharynx and Oesophagus in Women. The British Medical Journal, 15, 331-333. 
[16] Sugiura, Y., Nakagawa, M., Hashizume, T., Nemoto, E. and Kaseda, S. (2015) Iron Supplementation Improved Dysphagia Related to Plummer-Vinson Syndrome. The Keio Journal of Medicine, 64, 48-50. https://doi.org/10.2302/kjm.2014-0011-CR

[17] Taharaa, T., Shibataa, T., Okuboa, M., Yoshiokaa, D., Ishizukaa, T., Sumia, K., et al. (2014) A Case of Plummer-Vinson Syndrome Showing Rapid Improvement of Dysphagia and Esophageal Web after Two Weeks of Iron Therapy. Case Reports in Gastroenterology, 8, 211-215. https://doi.org/10.1159/000364820

[18] Vittal, K., Sankara Pandian, S. and Malarkodi, T. (2015) Plummer-Vinson Syndrome: A Case Report and Medical Management. IJSS Case Reports \& Reviews, 2 , 10-13.

[19] Mwenda, V., Njuguna, J. and Nzioka, A. (2016) Plummer-Vinson Syndrome with Improvement after Iron Repletion. Annals of African Surgery, 13, 81-83.

https://doi.org/10.4314/aas.v13i2.11

[20] Bakshia, S.S. and Lokesh Kumar, T. (2017) Plummer Vinson Syndrome. Acta Otorrinolaringológica Española.

[21] Demirci, F., Savafi, M.C., Kepkep, N., Okan, V., Yilmaz, M., Büyükberber, M., et al. (2005) Plummer-Vinson Syndrome and Dilation Therapy: A Report of Two Cases. The Turkish Journal of Gastroenterology, 16, 224-227.

[22] Chisholm, M. (1974) The Association between Webs, Iron and Post-Cricoid Carcinoma. Postgraduate Medical Journal, 50, 215-219.

https://doi.org/10.1136/pgmj.50.582.215

\section{Submit or recommend next manuscript to SCIRP and we will provide best} service for you:

Accepting pre-submission inquiries through Email, Facebook, LinkedIn, Twitter, etc. A wide selection of journals (inclusive of 9 subjects, more than 200 journals)

Providing 24-hour high-quality service

User-friendly online submission system

Fair and swift peer-review system

Efficient typesetting and proofreading procedure

Display of the result of downloads and visits, as well as the number of cited articles

Maximum dissemination of your research work

Submit your manuscript at: http://papersubmission.scirp.org/

Or contact ojgas@scirp.org 